\title{
SPh functionalized bridging-vinyliminium diiron and diruthenium complexes
}

\author{
Luigi Busetto ${ }^{\text {a }}$, Fabio Marchetti ${ }^{b 1}$, Rita Mazzoni ${ }^{\text {a }}$, Mauro Salmi ${ }^{\text {a }}$, \\ Stefano Zacchini ${ }^{\text {a }}$, Valerio Zanotti ${ }^{\text {a* }}$. \\ ${ }^{a}$ Dipartimento di Chimica Fisica e Inorganica, Università di Bologna, Viale Risorgimento 4, \\ I-40136 Bologna, Italy \\ ${ }^{b}$ Dipartimento di Chimica e Chimica Industriale, Università di Pisa, Via Risorgimento 35, I- \\ 56126 Pisa, Italy.
}

\begin{abstract}
The $-\mathrm{SPh}$ functionalized vinyliminium complexes $\left[\mathrm{Fe}_{2}\left\{\mu-\eta^{1}: \eta^{3}-\right.\right.$ $\left.\left.\mathrm{C}_{\gamma}\left(\mathrm{R}^{\prime}\right)=\mathrm{C}_{\beta}(\mathrm{SPh}) \mathrm{C}_{\alpha}=\mathrm{N}(\mathrm{Me})(\mathrm{R})\right\}(\mu-\mathrm{CO})(\mathrm{CO})(\mathrm{Cp})_{2}\right]\left[\mathrm{SO}_{3} \mathrm{CF}_{3}\right]\left[\mathrm{R}=\mathrm{Xyl}, \mathrm{R}^{\prime}=\mathrm{Me}, \mathbf{2 a} ; \mathrm{R}=\mathrm{Me}\right.$, $\mathrm{R}^{\prime}=\mathrm{Me}, \mathbf{2 b} ; \mathrm{R}=4-\mathrm{C}_{6} \mathrm{H}_{4} \mathrm{OMe}, \mathrm{R}^{\prime}=\mathrm{Me}, \mathbf{2} \mathbf{c} ; \mathrm{R}=\mathrm{Xyl}, \mathrm{R}^{\prime}=\mathrm{CH}_{2} \mathrm{OH}, \mathbf{2 d} ; \mathrm{R}=\mathrm{Me}, \mathrm{R}^{\prime}=$ $\left.\mathrm{CH}_{2} \mathrm{OH}, 2 \mathrm{e} ; \mathrm{Xyl}=2,6-\mathrm{Me}_{2} \mathrm{C}_{6} \mathrm{H}_{3}\right]$ are generated in high yields by treatment of the corresponding vinyliminium complexes $\left[\mathrm{Fe}_{2}\left\{\mu-\eta^{1}: \eta^{3}-\mathrm{C}_{\gamma}\left(\mathrm{R}^{\prime}\right)=\mathrm{C}_{\beta}(\mathrm{H}) \mathrm{C}_{\alpha}=\mathrm{N}(\mathrm{Me})(\mathrm{R})\right\}(\mu-\right.$ $\left.\mathrm{CO})(\mathrm{CO})(\mathrm{Cp})_{2}\right]\left[\mathrm{SO}_{3} \mathrm{CF}_{3}\right]$ (1a-e) with $\mathrm{NaH}$ in the presence of $\mathrm{PhSSPh}$. Likewise, the diruthenium complex $\left[\mathrm{Ru}_{2}\left\{\mu-\eta^{1}: \eta^{3}-\mathrm{C}_{\gamma}(\mathrm{Me})=\mathrm{C}_{\beta}(\mathrm{SPh}) \mathrm{C}_{\alpha}=\mathrm{N}(\mathrm{Me})(\mathrm{Xyl})\right\}(\mu-\right.$ $\left.\mathrm{CO})(\mathrm{CO})(\mathrm{Cp})_{2}\right]\left[\mathrm{SO}_{3} \mathrm{CF}_{3}\right](\mathbf{2 f})$ has been obtained from the corresponding vinyliminium complex $\left[\mathrm{Ru}_{2}\left\{\mu-\eta^{1}: \eta^{3}-\mathrm{C}_{\gamma}(\mathrm{Me})=\mathrm{C}_{\beta}(\mathrm{H}) \mathrm{C}_{\alpha}=\mathrm{N}(\mathrm{Me})(\mathrm{Xyl})\right\}(\mu-\mathrm{CO})(\mathrm{CO})(\mathrm{Cp})_{2}\right]$ (1f). The synthesis of $\mathbf{2 c}$ is accompanied by formation, in comparable amounts, of the aminocarbyne complex $\left[\mathrm{Fe}_{2}\left\{\mu-\mathrm{CN}(\mathrm{Me})\left(4-\mathrm{C}_{6} \mathrm{H}_{4} \mathrm{OMe}\right)\right\}(\mathrm{SPh})(\mu-\mathrm{CO})(\mathrm{CO})(\mathrm{Cp})_{2}\right](3)$.

The molecular structures of $\mathbf{2 d}, \mathbf{2 e}$ and $\mathbf{3}$ have been determined by X-ray diffraction studies.
\end{abstract}

Keywords: vinyliminium, zwitterionic complexes, disulfides, diiron complexes.

*Corresponding author. Tel.: +39 0512093695.

E-mail address: valerio.zanotti@unibo.it (V.Zanotti) 
${ }^{1}$ Fabio Marchetti, born in 1974 in Bologna, Italy. 


\section{Introduction}

Bridging vinyliminium complexes 1 [1] (Scheme 1) exhibit a remarkable reactivity, which results from the combination of two distinct features: the presence of an iminium group and the bridging coordination of the organic frame. Indeed, both iminium activation [2] and transformation of multisite bound organic frames [3] represent topics of current interest, for their effectiveness in providing new reactions and improved synthetic strategies. We exploited these activation effects to transform bridging vinyliminium ligands into new multifunctional coordinated species through new and unconventional reaction routes. These include proton removal from the $\mathrm{C}_{\beta}-\mathrm{H}$ in the presence of 'trapping' reagents, such as diazocompounds or group 16 elements. The reactions lead to the formation of diazine-bis alkylidenes I [4], and zwitterionic complexes II [5], respectively (Scheme 1).

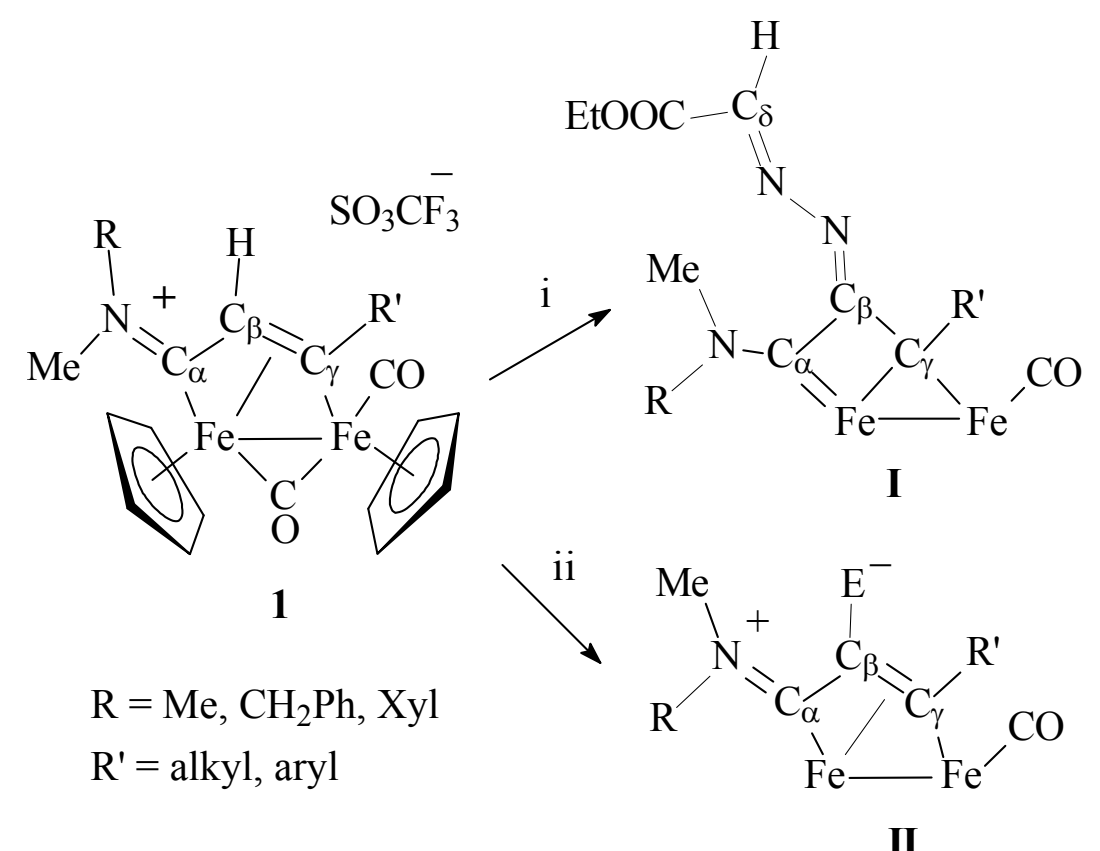

i: $\mathrm{NaH}, \mathrm{N}_{2} \mathrm{CH}(\mathrm{COOEt})$; ii: $\mathrm{NaH}, \mathrm{E}(\mathrm{E}=\mathrm{O}, \mathrm{S}, \mathrm{Se})$.

Scheme 1; ancillary $\mu-\mathrm{CO}$ and Cp ligands in I and II have been omitted for clarity. 
Herein we report an extension of these studies, aimed at investigating the deprotonation of vinyliminium complexes in the presence of $\mathrm{PhSSPh}$.

On the light of the influence that the substituents $\mathrm{R}$ and $\mathrm{R}$ ' exert on the reactivity of the complexes 1, a number of different vinyliminium complexes have been investigated. Likewise, the study includes a diruthenium vinyliminium complex, in order to evidence possible effects due to the nature of the metal atom.

\section{Results and discussion}

The vinyliminium complexes $\mathbf{1 a - f}$ react with $\mathrm{NaH}$, in THF at room temperature, in the presence of $\mathrm{PhSSPh}$, affording the corresponding phenylthiolate vinyliminium complexes $\mathbf{2 a -}$ f in about $70-80 \%$ yields (Scheme 2 ).

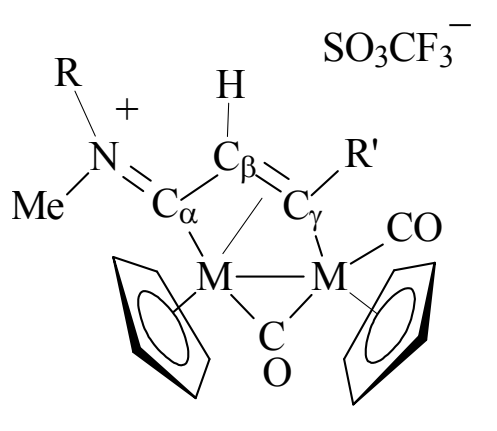

i) $\mathrm{PhSSPh}$

ii) $\mathrm{NaH}$

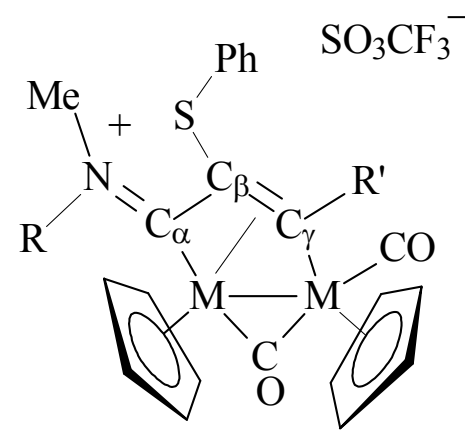

$\begin{array}{lllll} & \mathrm{M} & \mathrm{R} & \mathrm{R} & \\ \text { 1a } & \mathrm{Fe} & \mathrm{Xyl} & \mathrm{Me} & \mathbf{2 a} \\ \text { 1b } & \mathrm{Fe} & \mathrm{Me} & \mathrm{Me} & \mathbf{2 b} \\ \text { 1c } & \mathrm{Fe} & 4-\mathrm{C}_{6} \mathrm{H}_{4} \mathrm{OMe} & \mathrm{Me} & \mathbf{2 c} \\ \text { 1d } & \mathrm{Fe} & \mathrm{Xyl} & \mathrm{CH}_{2} \mathrm{OH} & \mathbf{2 d} \\ \text { 1e } & \mathrm{Fe} & \mathrm{Me} & \mathrm{CH}_{2} \mathrm{OH} & \mathbf{2 e} \\ \text { 1f } & \mathrm{Ru} & \mathrm{Xyl} & \mathrm{Me} & \mathbf{2 f}\end{array}$

\section{Scheme 2}

Complexes 2a-f, were purified by alumina chromatography and characterized by spectroscopy and elemental analysis. Moreover, the molecular structures of 2d and 2e have been ascertained by X-ray diffraction studies: the ORTEP molecular diagrams are shown in figures 1-2, whereas the most relevant bond distances and angles are reported in Table 1, where they are compared with a typical $\mathrm{C}_{\beta}$ substituted vinyliminium complex, i.e. cis- $\left[\mathrm{Fe}_{2}\{\mu-\right.$ $\left.\left.\eta^{1}: \eta^{3}-\mathrm{C}_{\gamma}(\mathrm{Me})=\mathrm{C}_{\beta}(\mathrm{Me}) \mathrm{C}_{\alpha}=\mathrm{N}(\mathrm{Me})(\mathrm{Xyl})\right\}(\mu-\mathrm{CO})(\mathrm{CO})(\mathrm{Cp})_{2}\right]\left[\mathrm{SO}_{3} \mathrm{CF}_{3}\right]$ (III) [1b]. A hydrogen 
bond exists in both structures between the $\mathrm{C}_{\gamma}-\mathrm{CH}_{2} \mathrm{OH}$ hydroxo group and one oxygen atom of the $\left[\mathrm{CF}_{3} \mathrm{SO}_{3}\right]^{-}$anion $[\mathrm{O}(1) \cdots \mathrm{O}(10) \# 1 \quad 2.833(10) \quad \AA, \quad \mathrm{O}(1)-\mathrm{H}(100) \quad 0.832(11) \quad \AA$, $\mathrm{H}(100) \cdots \mathrm{O}(10) \# 1 \quad 2.07(5) \quad \AA, \quad \mathrm{O}(1)-\mathrm{H}(100)-\mathrm{O}(10) \# 1 \quad 153(11)^{\circ}$ for $\mathbf{2 d}$; $\mathrm{O}(1) \cdots \mathrm{O}(10) \# 1$ 2.861(13) $\AA, \mathrm{O}(1)-\mathrm{H}(1 \mathrm{~A}) \quad 0.81(2) \AA, \mathrm{H}(1 \mathrm{~A}) \cdots \mathrm{O}(10) \# 1$ 2.07(3) $\AA, \mathrm{O}(1)-\mathrm{H}(1 \mathrm{~A})-\mathrm{O}(10) \# 1$ $164(8)^{\circ}$ and $\mathrm{O}(1)^{\cdots} \mathrm{O}\left(30^{\prime}\right) \# 1$ 2.681(16) $\AA, \mathrm{O}(1)-\mathrm{H}(1 \mathrm{~A})$ 0.81(2) $\AA, \mathrm{H}(1 \mathrm{~A}) \cdots \mathrm{O}(30$ ') \#1 2.01(6) $\AA, \mathrm{O}(1)-\mathrm{H}(1 \mathrm{~A})-\mathrm{O}\left(30^{\prime}\right) \# 1$ 140(8) ${ }^{\circ}$ for $\mathbf{2 d}$ ]. As it can be evinced from Table 1, the bonding parameters for both $\mathbf{2 d}$ and $\mathbf{2 e}$ are in perfect agreement with those previously reported for other vinyliminium complexes bearing a substituent on $\mathrm{C}_{\beta},[1 \mathrm{~b}, 5,6]$ confirming the usual $\mu$ $\eta^{1}: \eta^{3}$-coordination to the diiron frame of the unsaturated $C_{3}$ unit. Moreover, in keeping with previous findings, the $\mathrm{N}$-substituents in $\mathbf{2 d}$ adopt the $Z$ configuration in order to avoid steric repulsion with the $-\mathrm{SPh}$ group.

The overall result of the reaction shown in Scheme 1 consists in the replacement of the $\mathrm{C}_{\beta}-\mathrm{H}$ hydrogen with the $\mathrm{SPh}$ group. It should be noted that an alternative route to the introduction of a thiolate functionality in the bridging ligand is provided by two distinct reaction steps: a) generation of the zwitterionic species $\mathbf{I I}$; b) alkylation of the $\mathrm{S}$ atom (Scheme 3) [6].

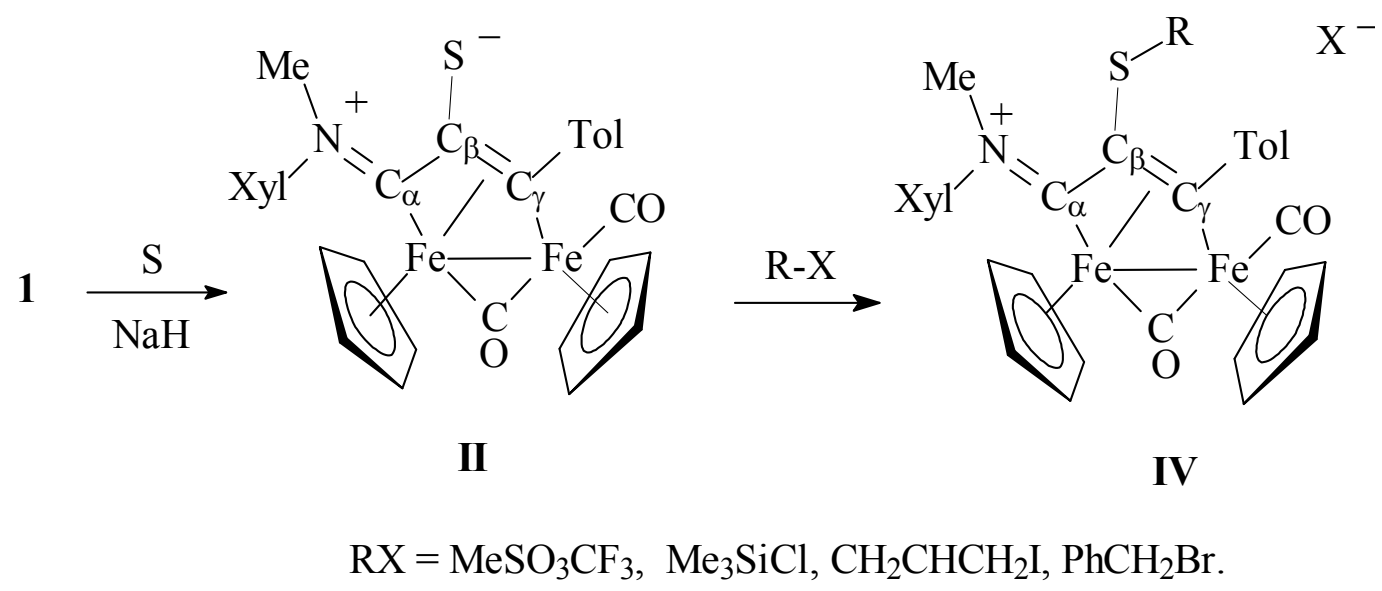

\section{Scheme 3}

Compared to the latter procedure, the reaction with $\mathrm{PhSSPh}$ has the advantage of being a direct, single step synthesis, although it is limited to the introduction of the $\mathrm{SPh}$ functionality.

Concerning the spectroscopic properties of 2a-f, these are consistent with the structures found in solid and very similar to those of the complexes of type IV, recently reported [6]. In particular, the IR spectra of 2a-f show the usual v-CO band pattern consisting 
of two absorptions due to the terminal and bridging carbonyls (e.g. for 2a at 1986 and 1826 $\mathrm{cm}^{-1}$, respectively), and one additional absorption attributed to the $\mathrm{C}_{\alpha}-\mathrm{N}$ interaction (e.g. for 2a at $1612 \mathrm{~cm}^{-1}$ ). The $\mathrm{NMR}$ spectra, in $\mathrm{CDCl}_{3}$ solution, reveal the presence of a single isomeric form. NOE studies carried on $\mathbf{2 a}, \mathbf{c}$ and $\mathbf{2 d}$ indicate that the N-substituents adopt the $Z$ configuration, with the steric demanding $X y l$ group pointing far from the $\mathrm{C}_{\beta}$-substituent, as shown in solid (2d), and usually found in related vinyliminium complexes. It should be noted that the precursors 1a-f display the opposite $E$ configuration and, therefore, the reactions must be accompanied by inversion of configuration at the iminium moiety.

Major features in the ${ }^{13} \mathrm{C}$ NMR spectra are given by the resonances due to the $\mathrm{C}_{3}$ bridging chain, which are similar to the corresponding values of the precursors 1a-f. The lowfield resonances of the $\mathrm{C}_{\alpha}$ and $\mathrm{C}_{\gamma}$ are consistent with their aminocarbene and bridging alkylidene character, respectively (e.g. for $\mathbf{2 a}$ at 227.4 and $214.8 \mathrm{ppm}$ ). Conversely, the $\mathrm{C}_{\beta}$ resonance is found at $c a .63 \mathrm{ppm}$.

The reactions investigated included the diruthenium complex 1f. The aim was to evidence possible effects due to the nature of the metal atom. Indeed, in a number of cases, dinuclear complexes containing ruthenium in the place of iron had shown rather different behavior [7]. However, this is not the case of 1f, which reacts exactly as the corresponding diiron complex 1a, and yields $\mathbf{2 f}$ (Scheme 2).

All of the reactions investigated are selective, in that they afford a single product, in a single isomeric form, with one exception concerning the reaction of 1c. In this case the synthesis of $\mathbf{2} \mathbf{c}$ is accompanied by the formation of comparable amounts of the aminocarbyne complex $\left[\mathrm{Fe}_{2}\left\{\mu-\mathrm{CN}(\mathrm{Me})\left(4-\mathrm{C}_{6} \mathrm{H}_{4} \mathrm{OMe}\right)\right\}(\mathrm{SPh})(\mu-\mathrm{CO})(\mathrm{CO})(\mathrm{Cp})_{2}\right]$ (3) (Scheme 4).
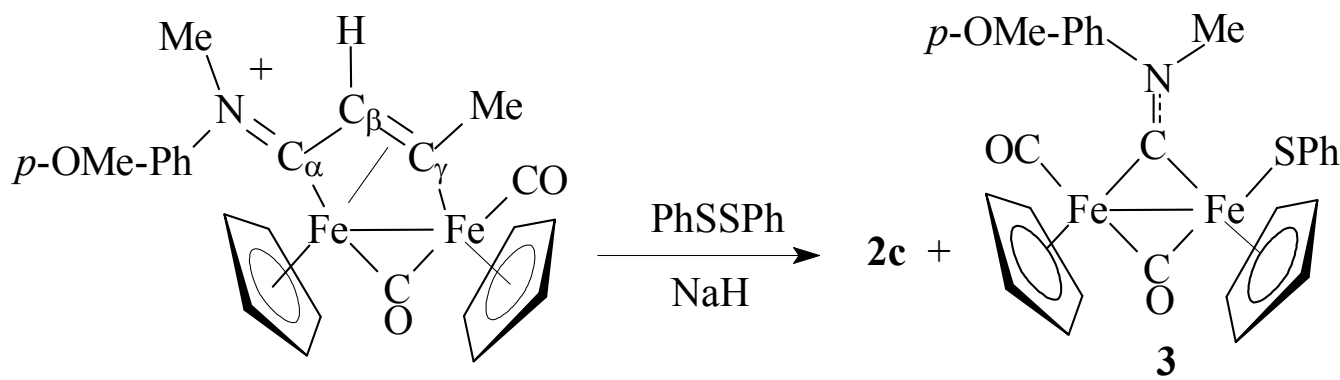

$1 \mathrm{c}$

\section{Scheme 4}


Compound 3 was identified by spectroscopy and X-ray diffraction studies (Figure 3 and Table 2). The bonding parameters of $\mathbf{3}$ are in the usual ranges for this class of complexes [8] as well as the $E$-configuration of the bridging aminocarbyne ligand.

The IR spectrum of 3 shows bands due to the carbonyl ligands, at 1968 and $1789 \mathrm{~cm}^{-1}$, respectively. Additional absorption at $1576 \mathrm{~cm}^{-1}$ accounts for the $\mu-\mathrm{CN}$ interaction.

Bridging aminocarbyne complexes analogous to $\mathbf{3}$ usually display, in solution, two isomeric forms due to the different orientations that $\mathrm{N}$ substituents can assume with respect to the non-equivalent $\mathrm{Fe}$ atoms as a consequence of the double bond character of the $\mu-\mathrm{C}-\mathrm{N}$ interaction [8]. Conversely, the NMR spectra of 3 contain a single set of resonances, indicating the presence of a single isomeric form. NOE investigations did not allow to establish the orientation adopted by the $p-\mathrm{OMeC}_{6} \mathrm{H}_{4}$ and $\mathrm{Me}$ substituents. However, it is plausible that these are arranged according to the $E$ configuration, coherently with what observed in solid. The salient feature of the ${ }^{13} \mathrm{C}$ NMR spectrum is represented by the resonance at $339.8 \mathrm{ppm}$, which accounts for the bridging aminocarbyne carbon.

The observed unique behaviour of $\mathbf{1 c}$ is presumably related to the presence of the $p$ OMe- $\mathrm{C}_{6} \mathrm{H}_{4}$ substituent, although no obvious explanation can be associated. It should be remarked that the reaction formally requires alkyne (propyne) deinsertion and elimination from the bridging ligand. Indeed, a number of vinyliminium complexes, such as $\left[\operatorname{Fe}_{2}\left\{\mu-\eta^{1}: \eta^{3}-\right.\right.$ $\left.\left.\mathrm{C}_{\gamma}\left(\mathrm{R}^{\prime}\right) \mathrm{C}_{\beta}(\mathrm{H}) \mathrm{C}_{\alpha} \mathrm{N}(\mathrm{Me}) \mathrm{R}\right\}(\mu-\mathrm{CO})(\mathrm{CO})(\mathrm{Cp})_{2}\right]\left[\mathrm{SO}_{3} \mathrm{CF}_{3}\right]\left(\mathrm{R}=\mathrm{Xyl}, \mathrm{Me} ; \mathrm{R}^{\prime}=\right.$ Tol, $\left.\mathrm{SiMe}_{3}\right)$, are known to undergo alkyne deinsertion, upon treatment with $\mathrm{NaH}$, affording acetylide complexes of type $\mathbf{V}$ (Scheme 5) [9]. Therefore, formation of $\mathbf{3}$ might also proceed through an acetylide intermediate, which, in turn, should be transformed into the final product (Scheme $5)$.

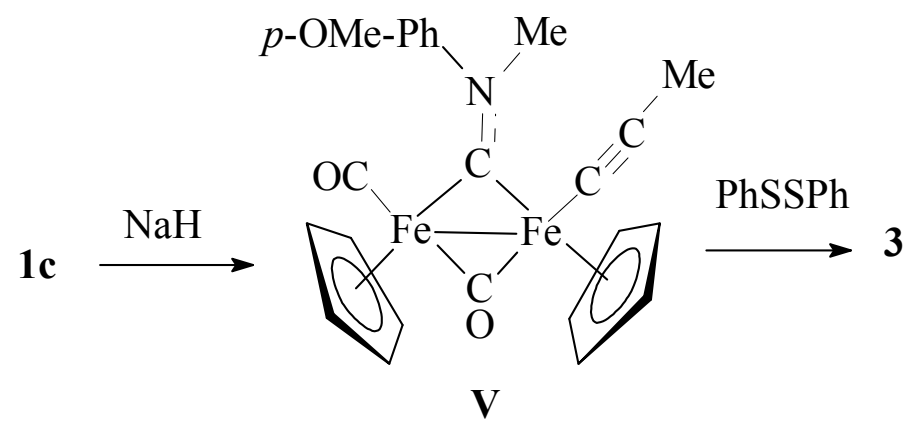

Scheme 5 
The reactions with phenyldisulfide, with formation of $\mathbf{2 a - f}$, deserve some further comments. Most of the reactions between disulfides and metal complexes consist in the oxidative addition with S-S bond cleavage and formation of thiolate ligands. This represents a well established synthetic approach for obtaining thiolate complexes, mostly dinuclear thiolato bridged, providing an alternative and advantageous route to the use of thiolate reagents [10]. Conversely, disulfide cleavage with formation of C-S bond involving coordinated ligands is less common, in spite of the considerable interest towards metal assisted C-S bond formation [11] including, for example, the metal-catalyzed stereoselective additions of disulfides and diselenides to alkynes and olefins [12]. The formation of the complexes 1a-f indicates that cleavage of a disulfide can be exploited to generate a C-S bond and introduce a phenyl thiolate functionality into a coordinated ligand. To the best of our knowledge, there is only one related example in which the $\mathrm{SPh}$ functionalization of a $\mathrm{Cp}$ ligand in a ferrocenyl complex, was obtained upon reaction with BuLi followed by treatment with PhSSPh [13].

A further consideration concerns the reaction mechanism. Presumably, relevant steps in the reaction sequence are the proton removal from $\mathrm{C}_{\beta}-\mathrm{H}$ and the consequent reaction with $\mathrm{PhSSPh}$, leading to the reductive cleavage of the S-S bond. However, alternative mechanisms based upon the homolitic cleavage of the disulfide operated by radical intermediate species should not be excluded. Indeed, radical complexes like $\left[\mathrm{Cr}(\mathrm{CO})_{3}\left(\mathrm{C}_{5} \mathrm{Me}_{5}\right)\right]^{*}$ are known to react with disulfides to generate thiolate derivatives $\left[\mathrm{Cr}(\mathrm{SR})(\mathrm{CO})_{3}\left(\mathrm{C}_{5} \mathrm{Me}_{5}\right)\right]$ [14]. Likewise, the diiron thiocarbyne complex $\left[\mathrm{Fe}_{2}(\mu-\mathrm{CSMe})(\mu-\mathrm{CO})(\mathrm{CO})_{2}(\mathrm{Cp})_{2}\right]\left[\mathrm{SO}_{3} \mathrm{CF}_{3}\right]$ was described to undergo one electron reduction generating a radical which, in turn, reacted with $\mathrm{PhSSPh}$ affording the thiolate complex $\left[\mathrm{Fe}_{2}(\mu-\mathrm{CSMe})(\mu-\mathrm{CO})(\mathrm{SPh})(\mathrm{CO})(\mathrm{Cp})_{2}\right]$ and, in minor amount, the dithiocarbene $\left[\mathrm{Fe}_{2}\{\mu-\mathrm{C}(\mathrm{SMe})(\mathrm{SPh})\}(\mu-\mathrm{CO})(\mathrm{CO})_{2}(\mathrm{Cp})_{2}\right][15]$.

In order to investigate the point and provide possible clues in favor of a radical mechanism, compounds 1d-f were treated with $\mathrm{PhSSPh}$ and sodium naphtalenide. The latter is a good one electron reducing agent, therefore it is expected to favor possible radical mechanisms. Unfortunately, the experiments were not conclusive: the reaction products were the same observed in the reactions with $\mathrm{NaH}$, although obtained in lower yield.

The reaction between vinyliminium ligands and $\mathrm{PhSSPh}$, shown in Scheme 2, is not general, in that other vinyliminium complexes, namely $\left[\mathrm{Fe}_{2}\left\{\mu-\eta^{1}: \eta^{3}-\right.\right.$ 
$\left.\left.\mathrm{C}\left(\mathrm{R}^{\prime}\right)=\mathrm{C}(\mathrm{H}) \mathrm{C}=\mathrm{N}(\mathrm{Me})(\mathrm{R})\right\}(\mu-\mathrm{CO})(\mathrm{CO})(\mathrm{Cp})_{2}\right]\left[\mathrm{SO}_{3} \mathrm{CF}_{3}\right]\left(\mathrm{R}=\mathrm{Xyl}, \mathrm{R}^{\prime}=\mathrm{Tol}=4-\mathrm{C}_{6} \mathrm{H}_{4} \mathrm{Me} ; \mathrm{R}=\right.$ $\mathrm{Xyl}, \mathrm{R}^{\prime}=\mathrm{SiMe}_{3} ; \mathrm{R}=\mathrm{Me}, \mathrm{R}^{\prime}=\mathrm{SiMe}_{3}$ ), upon treatment with $\mathrm{NaH}$ in the presence of $\mathrm{PhSSPh}$, failed to give the expected phenylthiolate functionalized vinyliminium complexes analogues to 2a-f. Conversely, these reactions afforded the species which are known to be produced when the corresponding vinyliminium complexes are treated with $\mathrm{NaH}$ in the absence of 'trapping' reagents [9]. In other words, these vinyliminium complexes react with $\mathrm{NaH}$, but the deprotonated intermediate evolve without involvement of the disulfide reagent.

\section{Conclusions}

In this paper we have revealed a simple, direct approach to the synthesis of phenyl thiolate functionalized vinyliminium complexes. Beside the $\mathrm{SPh}$ functionality, the bridging ligands display other functionalities containing heteroatoms: the $\mathrm{NMe}_{2}$ group and, for some of the complexes, the $\mathrm{OH}$ group. Therefore, the bridging ligand should be exploited to coordinate further metal fragments, or to produce other transformations, which will be subject of future studies.

\section{Experimental details}

\subsection{General}

All reactions were routinely carried out under a nitrogen atmosphere, using standard Schlenk techniques. Solvents were distilled immediately before use under nitrogen from appropriate drying agents. Chromatography separations were carried out on columns of deactivated alumina (4\% w/w water). Glassware was oven-dried before use. Infrared spectra were recorded at $298 \mathrm{~K}$ on a Perkin-Elmer Spectrum 2000 FT-IR spectrophotometer and elemental analyses were performed on a ThermoQuest Flash 1112 Series EA Instrument. ESI MS spectra were recorded on Waters Micromass ZQ 4000 with samples dissolved in $\mathrm{CH}_{3} \mathrm{CN}$. All NMR measurements were recorded at $298 \mathrm{~K}$ on Mercury Plus 400 instrument. The chemical shifts for ${ }^{1} \mathrm{H}$ and ${ }^{13} \mathrm{C}$ were referenced to internal TMS. The spectra were fully assigned via DEPT experiments and ${ }^{1} \mathrm{H},{ }^{13} \mathrm{C}$ correlation through gs-HSQC and gs-HMBC experiments. NOE measurements were recorded using the DPFGSE-NOE sequence. All the reagents were commercial products (Aldrich) of the highest purity available and used as 
received. Complexes 1a, 1b [1a], 1c [4], 1d, 1e [1b] and 1f [7a] were prepared as described in the literature

4.2. Synthesis of $\left[M_{2}\left\{\mu-\eta^{l}: \eta^{3}-C_{\gamma}\left(R^{\prime}\right)=C_{\beta}(S P h) C_{\alpha}=N(M e)(R)\right\}(\mu-C O)(C O)(C p)_{2}\right]\left[\mathrm{SO}_{3} C_{3}\right][M$ $=F e, R=X y l, R^{\prime}=M e, 2 a ; M=F e, R=R^{\prime}=M e, 2 b ; M=F e, R=4-C_{6} H_{4} O M e, R^{\prime}=M e$, 2c; $M=\mathrm{Fe}, \mathrm{R}=\mathrm{Xyl}, \mathrm{R}^{\prime}=\mathrm{CH}_{2} \mathrm{OH}, 2 \mathrm{~d} ; \mathrm{M}=\mathrm{Fe}, \mathrm{R}=\mathrm{Me}, \mathrm{R}^{\prime}=\mathrm{CH}_{2} \mathrm{OH}, 2 \boldsymbol{e} ; \mathrm{M}=\mathrm{Ru}, \mathrm{R}=\mathrm{Xyl}$, $\left.R^{\prime}=M e, 2 f\right]$

To a solution of $1 \mathbf{a}(120 \mathrm{mg}, 0.190 \mathrm{mmol})$ in THF $(10 \mathrm{~mL})$ were successively added $\mathrm{PhSSPh}$ (205 mg, $0.939 \mathrm{mmol}$ ) and $\mathrm{NaH}$ (46 mg, $1.92 \mathrm{mmol}$ ). The mixture was stirred for 20 minutes and then filtered on an alumina pad. Solvent removal and chromatography of the residue on alumina, using $\mathrm{CH}_{3} \mathrm{OH}$ as eluent, afforded $\mathbf{2 a}$ as a green band. Crystallization from $\mathrm{CH}_{2} \mathrm{Cl}_{2}$ solutions layered with $\mathrm{Et}_{2} \mathrm{O}$, at $-20{ }^{\circ} \mathrm{C}$ gave $\mathbf{2 a}$ as green solid. Yield: $99 \mathrm{mg}, 70 \%$. Anal. Calc. for $\mathrm{C}_{32} \mathrm{H}_{30} \mathrm{~F}_{3} \mathrm{Fe}_{2} \mathrm{NO}_{5} \mathrm{~S}_{2}$ : C, 51.84; H, 4.08; N, 1.89. Found: C, 51.96; H, 3.99; N, 1.99. IR $\left(\mathrm{CH}_{2} \mathrm{Cl}_{2}\right) v(\mathrm{CO}) 1986(\mathrm{vs}), 1826(\mathrm{~s}), v\left(\mathrm{C}_{\alpha} \mathrm{N}\right) 1612(\mathrm{~m}) \mathrm{cm}^{-1} \cdot{ }^{1} \mathrm{H}$ NMR $\left(\mathrm{CDCl}_{3}\right) \delta$ 7.45-7.13 (8 H, Ph and $\left.\mathrm{Me}_{2} \mathrm{C}_{6} H_{3}\right)$; 5.62, 4.95 (s, $\left.10 \mathrm{H}, \mathrm{Cp}\right) ; 4.10$ (s, $\left.3 \mathrm{H}, \mathrm{C}_{\gamma} \mathrm{Me}\right) ; 3.24$ (s, $3 \mathrm{H}$,

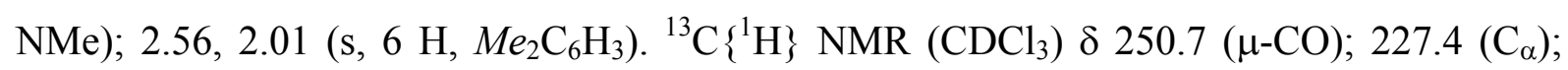
$214.8\left(\mathrm{C}_{\gamma}\right) ; 211.0(\mathrm{CO}) ; 140.7\left(\mathrm{C}_{\text {ipso Xyl }}\right) ; 135.1\left(\mathrm{C}_{\text {ipso Ph }}\right) ; 134.0-125.5\left(\mathrm{C}_{\text {arom }}\right)$; 92.3, $89.2(\mathrm{Cp})$; $63.0\left(\mathrm{C}_{\beta}\right) ; 49.7(\mathrm{NMe}) ; 38.8\left(\mathrm{C}_{\gamma} M e\right) ; 17.9,17.6\left(M_{2} \mathrm{C}_{6} \mathrm{H}_{3}\right)$.

Compounds $\mathbf{2 b - f}$ were prepared by the same procedure described for $\mathbf{2 a}$, by reacting $\mathbf{1 b}-\mathbf{f}$ with $\mathrm{PhSSPh} / \mathrm{NaH}$. Crystals of $\mathbf{2 d}$ and $\mathbf{2 e}$, suitable for X-ray analyses, were collected by $\mathrm{CH}_{2} \mathrm{Cl}_{2}$ solutions layered with diethyl ether, at $-20{ }^{\circ} \mathrm{C}$.

2b (yield: 80\%; colour: brown). Anal. Calc. for $\mathrm{C}_{25} \mathrm{H}_{24} \mathrm{~F}_{3} \mathrm{Fe}_{2} \mathrm{NO}_{5} \mathrm{~S}_{2}: \mathrm{C}, 46.10 ; \mathrm{H}, 3.71$; N, 2.15. Found: C, 46.16; H, 3.64; N, 2.21. IR $\left(\mathrm{CH}_{2} \mathrm{Cl}_{2}\right)$ v(CO) $1988(\mathrm{vs}), 1818(\mathrm{~s}), v\left(\mathrm{C}_{\alpha} \mathrm{N}\right) 1671$ (m) $\mathrm{cm}^{-1} .{ }^{1} \mathrm{H}$ NMR $\left(\mathrm{CDCl}_{3}\right) \delta$ 7.37-7.14 $(5 \mathrm{H}, \mathrm{Ph}) ; 5.50,4.99(\mathrm{~s}, 10 \mathrm{H}, \mathrm{Cp}) ; 4.02(\mathrm{~s}, 3 \mathrm{H}$, $\left.\mathrm{C}_{\gamma} \mathrm{Me}\right) ; 3.80,3.36$ (s, $\left.6 \mathrm{H}, \mathrm{NMe}\right) .{ }^{13} \mathrm{C}\left\{{ }^{1} \mathrm{H}\right\} \mathrm{NMR}\left(\mathrm{CDCl}_{3}\right) \delta 251.9(\mu-\mathrm{CO}) ; 223.6\left(\mathrm{C}_{\alpha}\right) ; 211.0$, $209.0\left(\mathrm{CO}\right.$ and $\left.\mathrm{C}_{\gamma}\right) ; 135.1\left(\mathrm{C}_{\text {ipso Ph}}\right) ; 129.8,127.0,126.9\left(\mathrm{C}_{\text {arom }}\right) ; 90.0,88.4(\mathrm{Cp}) ; 63.5\left(\mathrm{C}_{\beta}\right)$; $40.0\left(\mathrm{C}_{\gamma} \mathrm{Me}\right) ; 48.1,44.9(\mathrm{NMe})$.

2c (yield: 38\%; colour: brown). Anal. Calc. for $\mathrm{C}_{31} \mathrm{H}_{28} \mathrm{~F}_{3} \mathrm{Fe}_{2} \mathrm{NO}_{6} \mathrm{~S}_{2}: \mathrm{C}, 50.09 ; \mathrm{H}, 3.80 ; \mathrm{N}$, 1.88. Found: C, 50.00; H, 3.69; N, 1.85. IR $\left(\mathrm{CH}_{2} \mathrm{Cl}_{2}\right) v(\mathrm{CO}) 1995$ (vs), $1820(\mathrm{~s}), v\left(\mathrm{C}_{\alpha} \mathrm{N}\right) 1636$ (m) $\mathrm{cm}^{-1} .{ }^{1} \mathrm{H}$ NMR $\left(\mathrm{CDCl}_{3}\right) \delta 7.00,6.80,6.68,6.30\left(9 \mathrm{H}, \mathrm{Ph}\right.$ and $\left.\mathrm{C}_{6} \mathrm{H}_{4} \mathrm{OMe}\right) ; 5.56,5.28(\mathrm{~s}$, $10 \mathrm{H}, \mathrm{Cp}) ; 4.33$ (s, $3 \mathrm{H}, \mathrm{NMe}) ; 4.02$ (s, $\left.3 \mathrm{H}, \mathrm{C}_{\gamma} \mathrm{Me}\right) ; 3.52$ (s, $\left.3 \mathrm{H}, \mathrm{OMe}\right) .{ }^{13} \mathrm{C}\left\{{ }^{1} \mathrm{H}\right\} \mathrm{NMR}$ 
$\left(\mathrm{CDCl}_{3}\right) \delta 252.9(\mu-\mathrm{CO}) ; 228.4\left(\mathrm{C}_{\alpha}\right) ; 214.0\left(\mathrm{C}_{\gamma}\right) ; 210.7(\mathrm{CO}) ; 159.1-114.4\left(\mathrm{C}_{\text {arom }}\right) ; 92.5,89.6$ $(\mathrm{Cp}) ; 64.2\left(\mathrm{C}_{\beta}\right) ; 55.9(\mathrm{OMe}) ; 49.0(\mathrm{NMe}) ; 40.2\left(\mathrm{C}_{\gamma} M e\right)$.

2d (yield: $81 \%$; colour: brown). Anal. Calc. for $\mathrm{C}_{32} \mathrm{H}_{30} \mathrm{~F}_{3} \mathrm{Fe}_{2} \mathrm{NO}_{6} \mathrm{~S}_{2}: \mathrm{C}, 50.75 ; \mathrm{H}, 3.99 ; \mathrm{N}$, 1.85. Found: C, 50.83; H, 4.06; N, 1.84. IR $\left(\mathrm{CH}_{2} \mathrm{Cl}_{2}\right) v(\mathrm{CO}) 1984(\mathrm{vs}), 1822(\mathrm{~s}), v\left(\mathrm{C}_{\alpha} \mathrm{N}\right) 1614$ (m) $\mathrm{cm}^{-1} .{ }^{1} \mathrm{H}$ NMR $\left(\mathrm{CDCl}_{3}\right) \delta$ 7.45-7.21 (8 H, Ph and $\left.\mathrm{Me}_{2} \mathrm{C}_{6} H_{3}\right) ; 6.72$ (br, $\left.1 \mathrm{H}, \mathrm{OH}\right) ; 6.21$, $5.81\left(\mathrm{dd},{ }^{2} \mathrm{~J}_{\mathrm{HH}}=14.3 \mathrm{~Hz},{ }^{3} \mathrm{~J}_{\mathrm{OH}}=2.9 \mathrm{~Hz}, 2 \mathrm{H}, \mathrm{CH}_{2} \mathrm{OH}\right) ; 5.61,4.90(\mathrm{~s}, 10 \mathrm{H}, \mathrm{Cp}) ; 3.18(\mathrm{~s}, 3 \mathrm{H}$, $\mathrm{NMe}) ; 2.57,2.02$ (s, $\left.6 \mathrm{H}, \mathrm{Me}_{2} \mathrm{C}_{6} \mathrm{H}_{3}\right) .{ }^{13} \mathrm{C}\left\{{ }^{1} \mathrm{H}\right\} \mathrm{NMR}\left(\mathrm{CDCl}_{3}\right) \delta 251.5$ ( $\mu$-CO); $226.9\left(\mathrm{C}_{\alpha}\right)$; $219.2\left(\mathrm{C}_{\gamma}\right) ; 211.1(\mathrm{CO}) ; 140.6\left(\mathrm{C}_{\mathrm{ipso} \mathrm{Xyl}}\right) ; 135.7\left(\mathrm{C}_{\mathrm{ipso} \mathrm{Ph}}\right) ; 134.1-126.1\left(\mathrm{C}_{\mathrm{arom}}\right) ;$ 91.6, $88.5(\mathrm{Cp})$; $73.0\left(\mathrm{CH}_{2}\right) ; 62.9\left(\mathrm{C}_{\beta}\right) ; 50.0(\mathrm{NMe}) ; 18.0,17.7\left(\mathrm{Me}_{2} \mathrm{C}_{6} \mathrm{H}_{3}\right)$.

2e (yield: 80\%; colour: green). Anal. Calc. for $\mathrm{C}_{25} \mathrm{H}_{24} \mathrm{~F}_{3} \mathrm{Fe}_{2} \mathrm{NO}_{6} \mathrm{~S}_{2}$ : C, 45.00; H, 3.63; N, 2.10 . Found: C, 45.06; H, 3.71; N, 2.04. IR $\left(\mathrm{CH}_{2} \mathrm{Cl}_{2}\right) v(\mathrm{CO}) 1991$ (vs), 1815 (s), v( $\left.\mathrm{C}_{\alpha} \mathrm{N}\right) 1670(\mathrm{~m})$ $\mathrm{cm}^{-1} .{ }^{1} \mathrm{H}$ NMR $\left(\mathrm{CDCl}_{3}\right) \delta$ 7.37-7.14 $(5 \mathrm{H}, \mathrm{Ph}) ; 5.91,5.83\left(\mathrm{dd}, 2 \mathrm{H},{ }^{2} \mathrm{~J}_{\mathrm{HH}}=11 \mathrm{~Hz}, \mathrm{CH}_{2} \mathrm{OH}\right)$; 5.42, 5.04 (s, $10 \mathrm{H}, \mathrm{Cp}) ; 5.17$ (br, $1 \mathrm{H}, \mathrm{OH}) ; 3.83,3.41(\mathrm{~s}, 6 \mathrm{H}, \mathrm{NMe}) .{ }^{13} \mathrm{C}\left\{{ }^{1} \mathrm{H}\right\} \mathrm{NMR}\left(\mathrm{CDCl}_{3}\right)$ $\delta 253.5(\mu-\mathrm{CO}) ; 222.8\left(\mathrm{C}_{\alpha}\right) ; 210.5,209.5\left(\mathrm{CO}\right.$ and $\left.\mathrm{C}_{\gamma}\right) ; 135.6\left(\mathrm{C}_{\mathrm{ipso} \mathrm{Ph}}\right) ; 129.6,127.6,127.0$ $(\mathrm{Ph})$; 90.8, $88.0(\mathrm{Cp}) ; 72.9\left(\mathrm{CH}_{2}\right) ; 63.9\left(\mathrm{C}_{\beta}\right) ; 48.8,45.6(\mathrm{NMe})$.

2f (yield: 82\%; colour: ochre yellow). Anal. Calc. for $\mathrm{C}_{32} \mathrm{H}_{30} \mathrm{~F}_{3} \mathrm{NO}_{5} \mathrm{Ru}_{2} \mathrm{~S}_{2}: \mathrm{C}, 46.20 ; \mathrm{H}, 3.64$; $\mathrm{N}, 1.68$. Found: C, 46.22; H, 3.55; N, 1.72. IR $\left(\mathrm{CH}_{2} \mathrm{Cl}_{2}\right) v(\mathrm{CO}) 1999$ (vs), $1825(\mathrm{~s}), v\left(\mathrm{C}_{\alpha} \mathrm{N}\right)$ $1634(\mathrm{~m}) \mathrm{cm}^{-1} .{ }^{1} \mathrm{H}$ NMR $\left(\mathrm{CDCl}_{3}\right) \delta$ 7.37-7.00 (8 H, Ph and $\left.\mathrm{Me}_{2} \mathrm{C}_{6} H_{3}\right) ; 5.72,5.46(\mathrm{~s}, 10 \mathrm{H}$, $\mathrm{Cp}) ; 5.52$ (s, $\left.3 \mathrm{H}, \mathrm{C}_{\gamma} \mathrm{Me}\right) ; 3.83$ (s, $\left.3 \mathrm{H}, \mathrm{NMe}\right) ; 1.93,1.84$ (s, $\left.6 \mathrm{H}, M_{2} \mathrm{C}_{6} \mathrm{H}_{3}\right) .{ }^{13} \mathrm{C}\left\{{ }^{1} \mathrm{H}\right\} \mathrm{NMR}$ $\left(\mathrm{CDCl}_{3}\right) \delta 228.4(\mu-\mathrm{CO}) ; 221.8\left(\mathrm{C}_{\alpha}\right) ; 197.7(\mathrm{CO}) ; 184.9\left(\mathrm{C}_{\gamma}\right) ; 143.8\left(\mathrm{C}_{\mathrm{ipso} \mathrm{Xyl}}\right) ; 132.4-125.6$ $\left(\mathrm{C}_{\text {arom }}\right) ; 92.4,88.9(\mathrm{Cp}) ; 59.5\left(\mathrm{C}_{\beta}\right) ; 57.1\left(\mathrm{C}_{\gamma} M e\right) ; 47.1(\mathrm{NMe}) ; 17.5,17.4\left(\mathrm{Me}_{2} \mathrm{C}_{6} \mathrm{H}_{3}\right)$.

\subsection{Synthesis of $\left[\mathrm{Fe}_{2}\left\{\mu-\mathrm{CN}(\mathrm{Me})\left(4-\mathrm{C}_{6} \mathrm{H}_{4} \mathrm{OMe}\right)\right\}(\mathrm{SPh})(\mu-\mathrm{CO})(\mathrm{CO})(\mathrm{Cp})_{2}\right](3)$.}

Complex 3 was obtained in the reaction of 1 c with $\mathrm{PhSSPh} / \mathrm{NaH}$, together with 2c. Chromatography on alumina, using $\mathrm{CH}_{2} \mathrm{Cl}_{2}$ as eluent, gave 3 as second green band, which was collected and evaporated to dryness under reduced pressure. Yield: 49\%. Crystals suitable for X-ray diffraction were obtained by a $\mathrm{CH}_{2} \mathrm{Cl}_{2}$ solution layered with n-pentane, at $20{ }^{\circ} \mathrm{C}$. Anal. Calc. for $\mathrm{C}_{27} \mathrm{H}_{25} \mathrm{Fe}_{2} \mathrm{NO}_{3} \mathrm{~S}: \mathrm{C}, 58.40 ; \mathrm{H}, 4.54 ; \mathrm{N}, 2.52$. Found: C, 58.36; H, 4.45; $\mathrm{N}, 2.59$. IR $\left(\mathrm{CH}_{2} \mathrm{Cl}_{2}\right) v(\mathrm{CO}) 1968$ (vs), $1789(\mathrm{~s}), v\left(\mathrm{C}_{\alpha} \mathrm{N}\right) 1576(\mathrm{w}) \mathrm{cm}^{-1} .{ }^{1} \mathrm{H} \mathrm{NMR}\left(\mathrm{CDCl}_{3}\right) \delta$ 7.75-6.99 (9 H, Ph and $\left.\mathrm{C}_{6} \mathrm{H}_{4} \mathrm{OMe}\right)$; 4,76, 4.68 (s, $\left.10 \mathrm{H}, \mathrm{Cp}\right)$; 4.24 (s, $\left.3 \mathrm{H}, \mathrm{NMe}\right) ; 3.90$ (s, $3 \mathrm{H}$, OMe). ${ }^{13} \mathrm{C}\left\{{ }^{1} \mathrm{H}\right\}$ NMR $\left(\mathrm{CDCl}_{3}\right) \delta 339.8(\mu-\mathrm{CN}) ; 265.0(\mu-\mathrm{CO}) ; 214.2(\mathrm{CO}) ; 158.8\left(\mathrm{C}_{\text {ipso-C6H4 }}\right)$; 144.8-114.5 ( $\left.\mathrm{C}_{\text {arom }}\right)$; 87.4, 86.5 (Cp); 55.6 (OMe); $53.3(\mathrm{NMe})$. 


\subsection{X-ray Crystallography for $2 \boldsymbol{d}, \mathbf{2 e}$ and $3 \cdot 0.5 \mathbf{E t}_{2} \mathrm{O}$}

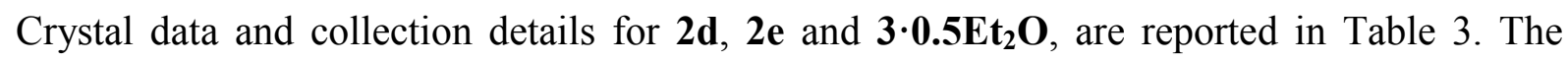
diffraction experiments were carried out on a Bruker APEX II (for 2d and 3.0.5Et $\mathbf{2} \mathbf{O}$ ) and on a Bruker AXS SMART 2000 (for 2e) diffractometer equipped with a CCD detector using $M o$ $K \alpha$ radiation. Data were corrected for Lorentz polarization and absorption effects (empirical absorption correction SADABS) [16]. Structures were solved by direct methods and refined by full-matrix least-squares based on all data using $F^{2}$ [17]. Hydrogen atoms were fixed at calculated positions and refined by a riding model, except the O-bonded hydrogens in both $\mathbf{2 d}$ and 2e which were located in the Fourier map and refined isotropically using the 1.2 fold $U_{\text {iso }}$ value of the parent $O$-atom. Restraints were applied to the O-H bonds (DFIX 0.830 .01 line in SHELX). All non-hydrogen atoms were refined with anisotropic displacement parameters, unless otherwise stated. The crystals of $\mathbf{2 d}$ were of very low quality and the data have been cut at low angle; even though the connectivity is certain, bond distances and angles have to be considered with care. Hydrogen bonds exist in the structures of $\mathbf{2 d}$ and $\mathbf{2 e}$, between the $\mathrm{O}(1)$ $\mathrm{H}$ groups and the oxygen atoms of the triflate anion. Similar $U$ restraints were applied to the C-atoms in $2 \mathrm{~d}$ (s.u. 0.01) and 2e (s.u. 0.02, only to the Cp ligands). The F- and O-atoms of the $\mathrm{CF}_{3} \mathrm{SO}_{3}{ }^{-}$anion (located in a general position) in $\mathbf{2 e}$ are disordered; disordered atomic positions were split and refined isotropically using similar distance and similar $U$ restraints

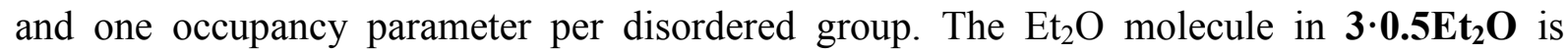
disordered over two equally populated positions related by an inversion centre; in this case, an occupancy factor of 0.5 was assigned to the independent image of the moelcule and, then, refined isotropically.

\section{Acknowledgement}

We thank the Ministero dell'Università e della Ricerca Scientifica e Tecnologica (M.I.U.R.) (project: 'New strategies for the control of reactions: interactions of molecular fragments with metallic sites in unconventional species') and the University of Bologna for financial support. 


\section{Supplementary Material}

Crystallographic data for the structural analyses have been deposited with the Cambridge Crystallographic Data Centre, CCDC no. 691641 for 2d, 691639 for 2e and 691640 for 3. Copies of this information can be obtained free of charge from the Director, CCDC, 12 Union Road, Cambridge CB2 1EZ, UK (fax: +44-1233-336033; deposit@ccdc.cam.ac.uk or www.ccdc.cam.ac.uk). 


\section{References}

[1] (a) V. G. Albano, L. Busetto, F. Marchetti, M. Monari, S. Zacchini, V. Zanotti, Organometallics 22 (2003) 1326;

(b) V. G. Albano, L. Busetto, F. Marchetti, M. Monari, S. Zacchini, V. Zanotti, J. Organomet. Chem. 689 (2004) 528.

[2] (a) A. Erkkilä, I. Majander, P. M. Pihko, Chem. Rev. 107 (2007) 5416;

(b) S. Mukherjee, J. W. Yang, S. Hoffmann, B. List, Chem. Rev. 107 (2007) 5471;

(c) B. List, Acc. Chem. Res. 37 (2004) 548;

(d) G. Lelais, D. W. C. MacMillan, Aldrichimica Acta 39 (2006) 79.

[3] (a) V. Ritleng, M. J. Chetcuti, Chem. Rev. 107 (2007) 797;

(b) M. Cowie, Can. J. Chem. 83 (2005) 1043;

(c) P. Braunstein, J. Rosé, Metal Cluster in Chemistry, P. Braunstein, L. A. Oro, P. R. Raithby Eds.; Wiley - VCH: Weinheim 1999, 616.

[4] L. Busetto, F. Marchetti, S. Zacchini, V. Zanotti, Organometallics 26 (2007) 3577.

[5] L. Busetto, F. Marchetti, S. Zacchini, V. Zanotti, Organometallics 25 (2006) 4808.

[6] L. Busetto, M. Dionisio, F. Marchetti, R. Mazzoni, M. Salmi, S. Zacchini, V. Zanotti, J. Organomet. Chem. 693 (2008) 2385.

[7] (a) L. Busetto, F. Marchetti, S. Zacchini, V. Zanotti, J. Organomet. Chem. 691 (2006) 2424;

(b) L. Busetto, F. Marchetti, S. Zacchini, V. Zanotti, Eur. J. Inorg. Chem. (2004) 1494.

[8] (a) K. Boss, M. G. Cox, C. Dowling, A. R. Manning, J. Organomet. Chem. 612 (2000) 18 ;

(b) K. Boss, C. Dowling, A. R. Manning, J. Organomet. Chem. 509 (1996) 197;

(c) G. Cox, C. Dowling, A. R. Manning, P. McArdle, D. Cunningham, J. Organomet. Chem. 438 (1992) 143;

(d) S. Willis, A. R. Manning, F. S. Stephens, J. Chem. Soc. Dalton Trans. 1980, 186;

(e) V. G. Albano, L. Busetto, F. Marchetti, M. Monari, V. Zanotti, J. Organomet. Chem. 649 (2002) 64;

(f) L. Busetto, F. Marchetti, S. Zacchini, V. Zanotti, Inorg. Chim. Acta 358 (2005) 1204 ;

(g) V. G. Albano, L. Busetto, F. Marchetti, M. Monari, S. Zacchini, V. Zanotti, Zeit. Naturf. B (2007) 427.

[9] L. Busetto, F. Marchetti, S. Zacchini, V. Zanotti, Organometallics 24 (2005) 2297. 
[10] (a) E. Becker, K. Mereiter, R. Schmid, K. Kirchner, Organometallics 23 (2004) 2876;

(b) M. Md. Hossain, H.-M. Lin, J. Zhu, Z. Lin, S.-G. Shyu, Organometallics 25 (2006) 440;

(c) W.-F. Liaw, C.-H. Hsieh, S.-M. Peng, G.-H. Lee, Inorg. Chim. Acta 332 (2002) 153

(d) C.-M. Lee, G.-Y. Lin, C.-H. Hsieh, C.-H. Hu, G.-H. Lee, S.-M. Peng, W.-F. Liaw, J. Chem. Soc., Dalton Trans. (1999) 2393;

(e) W.-F. Liaw, C.-H. Chen, G.-H. Lee, S.-M. Peng, Organometallics 17 (1998) 2370;

(f) F. Y. Petillon, P. Schollhammer, J. Talarmin, K. W. Muir, Coord. Chem. Rev. 178180 (1998) 203;

(g) R. F. Lang, T. D. Ju, G. Kiss, C. D. Hoff, J. C. Bryan, G. J. Kubas, Inorg. Chem. 33 (1994) 3899.

[11] (a) K. Matsumoto, H. Sugiyama, J. Organomet. Chem. 689 (2004) 4564;

(b) K. Matsumoto, H. Sugiyama, Acc. Chem. Res. 35 (2002) 915.

[12] (a) I. P. Beletskaya, V. P. Ananikov, Eu. J. Org. Chem. (2007) 3431;

(b) T. Kondo, S. Uenoyama, K.Fujita, T. Mitsudo, J. Am. Chem. Soc. 121 (1999) 482.

[13] H. Seo, H. Park, B.Y. Kim, J. H. Lee, S. U. Son, Y. K. Chung, Organometallics 22 (2003) 618 .

[14] T. D. Ju, K. B. Capps, R. F. Lang, G. C. Roper, C. D. Hoff, Inorg. Chem. 36 (1997) 614.

[15] N. C. Schroeder, R. J. Angelici, J. Am. Chem.Soc. 108 (1986) 3688.

[16] G. M. Sheldrick, SADABS, Program for empirical absorption correction, University of Göttingen, Germany, 1996.

[17] G. M. Sheldrick, SHELX97, Program for crystal structure determination, University of Göttingen, Germany, 1997. 
Figure 1. Molecular structure of $\left[\mathrm{Fe}_{2}\left\{\mu-\eta^{1}: \eta^{3}-\mathrm{C}_{\gamma}\left(\mathrm{CH}_{2} \mathrm{OH}\right)=\mathrm{C}_{\beta}(\mathrm{SPh}) \mathrm{C}_{\alpha}=\mathrm{N}(\mathrm{Me})(\mathrm{Xyl})\right\}(\mu-\right.$ $\left.\mathrm{CO})(\mathrm{CO})(\mathrm{Cp})_{2}\right]\left[\mathrm{SO}_{3} \mathrm{CF}_{3}\right]$ (2d), with key atoms labeled (all $\mathrm{H}$-atoms, except $\mathrm{H}(100)$, have been omitted for clarity). Thermal ellipsoids are at the $30 \%$ probability level.

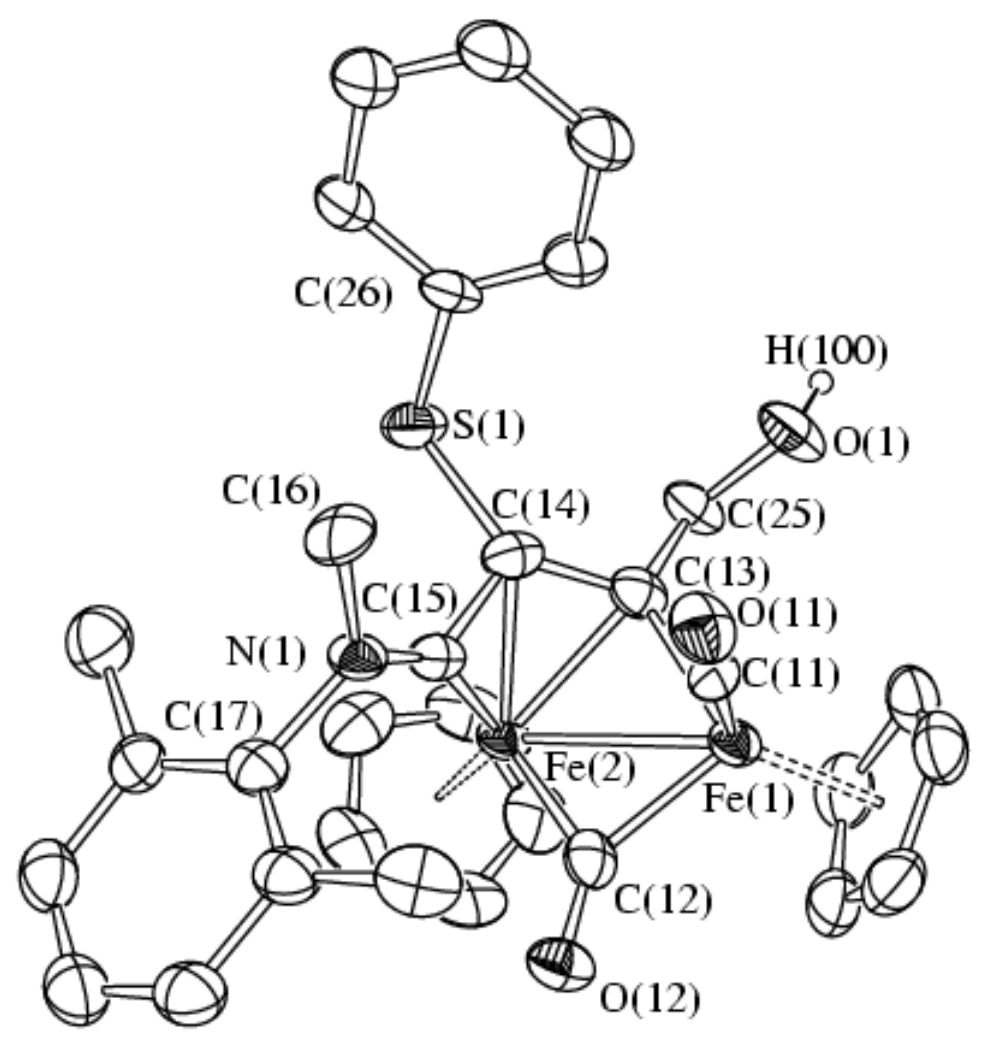


Figure 2. Molecular structure of $\left[\mathrm{Fe}_{2}\left\{\mu-\eta^{1}: \eta^{3}-\mathrm{C}_{\gamma}\left(\mathrm{CH}_{2} \mathrm{OH}\right)=\mathrm{C}_{\beta}(\mathrm{SPh}) \mathrm{C}_{\alpha}=\mathrm{N}(\mathrm{Me})_{2}\right\}(\mu-\right.$ $\left.\mathrm{CO})(\mathrm{CO})(\mathrm{Cp})_{2}\right]\left[\mathrm{SO}_{3} \mathrm{CF}_{3}\right]$ (2e) with key atoms labeled (all $\mathrm{H}$-atoms, except $\mathrm{H}(1 \mathrm{a})$, have been omitted for clarity). Thermal ellipsoids are at the $30 \%$ probability level.

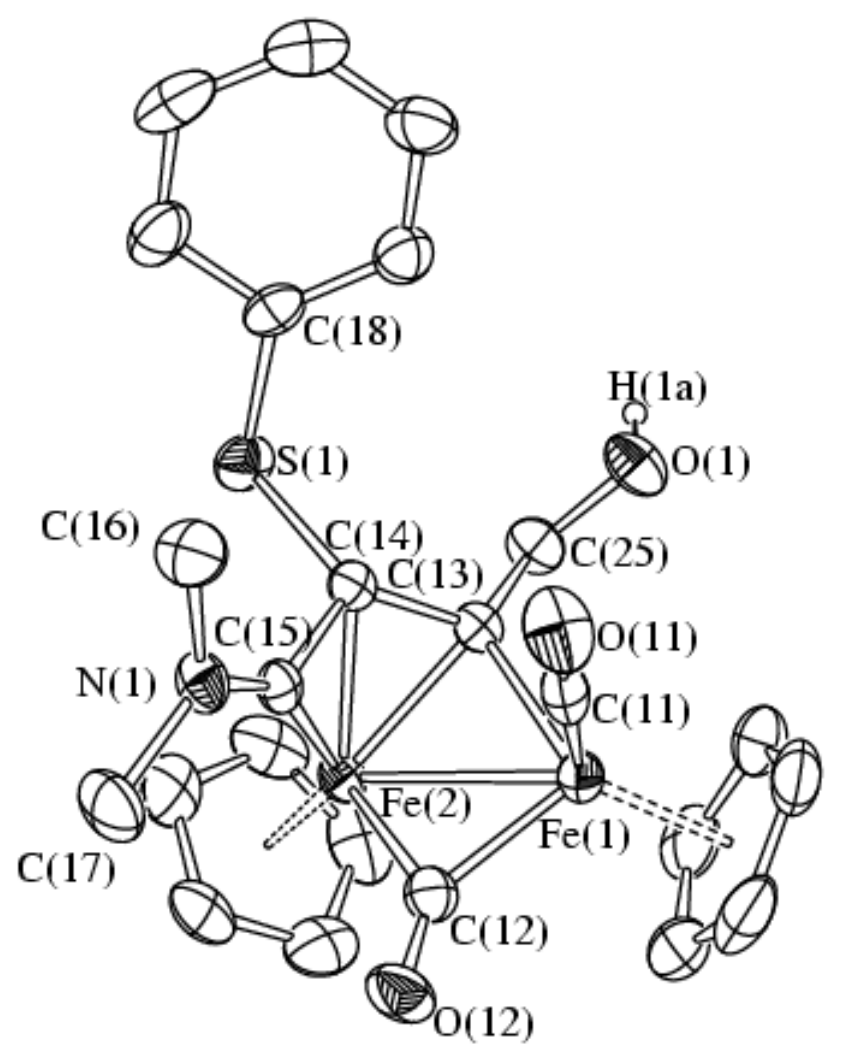


Figure 3. Molecular structure of $\left[\mathrm{Fe}_{2}\left\{\mu-\mathrm{CN}(\mathrm{Me})\left(4-\mathrm{C}_{6} \mathrm{H}_{4} \mathrm{OMe}\right)\right\}(\mathrm{SPh})(\mu-\mathrm{CO})(\mathrm{CO})(\mathrm{Cp})_{2}\right](3)$ with key atoms labeled (all $\mathrm{H}$-atoms have been omitted for clarity). Thermal ellipsoids are at the $30 \%$ probability level.

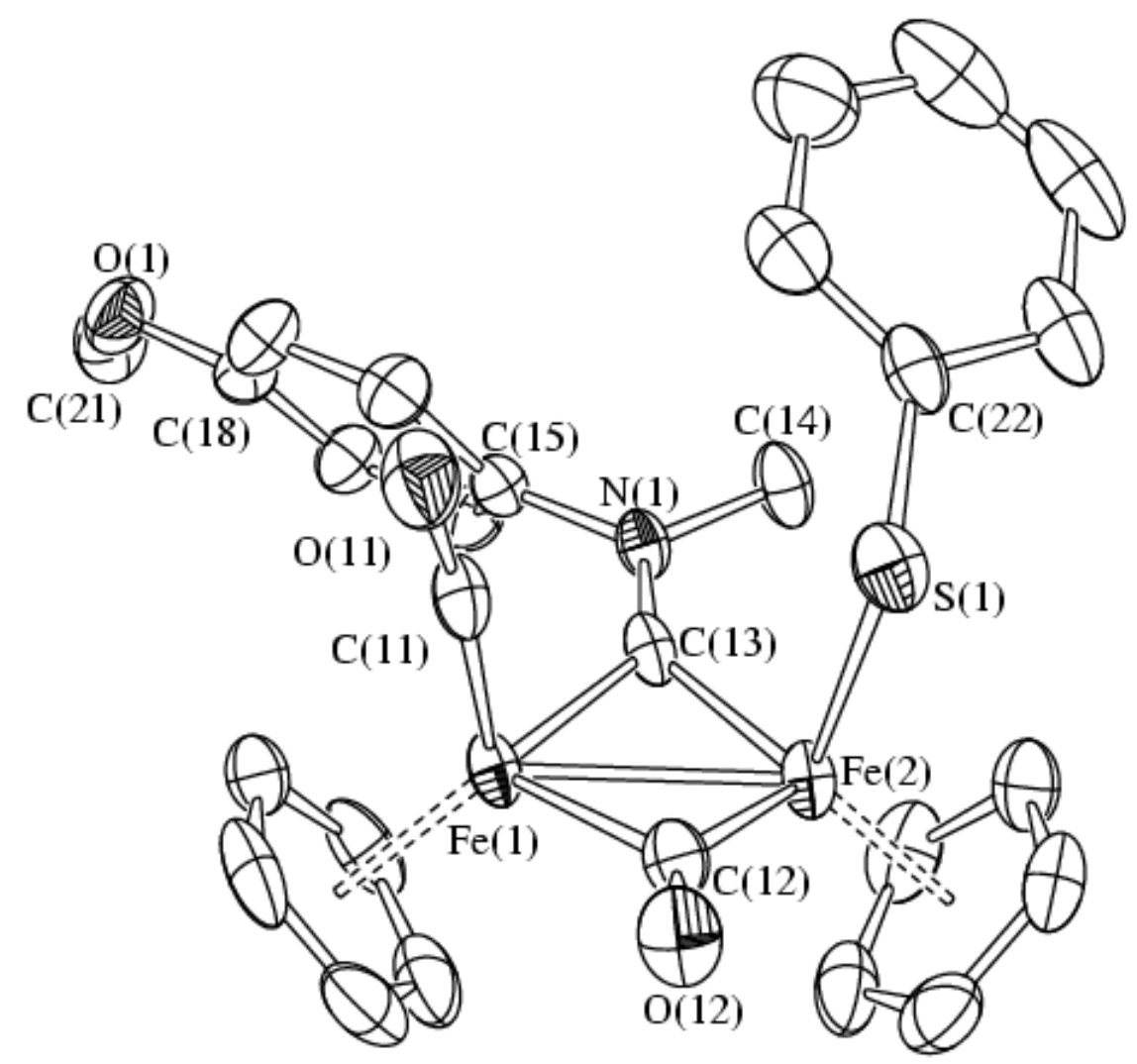


Table 1. Selected bond lengths $(\AA)$ and angles $\left(^{\circ}\right)$ for $\mathbf{2 d}$ and $2 \mathrm{e}$. The most relevant bonding parameters of the $\mathrm{C}_{\beta}$ substituted vinyliminium complex $c i s-\left[\mathrm{Fe}_{2}\left\{\mu-\eta^{1}: \eta^{3}-\right.\right.$ $\left.\left.\mathrm{C}_{\gamma}(\mathrm{Me})=\mathrm{C}_{\beta}(\mathrm{Me}) \mathrm{C}_{\alpha}=\mathrm{N}(\mathrm{Me})(\mathrm{Xyl})\right\}(\mu-\mathrm{CO})(\mathrm{CO})(\mathrm{Cp})_{2}\right]\left[\mathrm{SO}_{3} \mathrm{CF}_{3}\right]($ III) [1b] are reported as well for sake of comparison.

\begin{tabular}{|c|c|c|c|}
\hline & 2d & $2 \mathrm{e}$ & III \\
\hline $\mathrm{Fe}(1)-\mathrm{Fe}(2)$ & $2.558(2)$ & $2.5460(11)$ & $2.562(1)$ \\
\hline $\mathrm{Fe}(1)-\mathrm{C}(11)$ & $1.742(12)$ & $1.763(7)$ & $1.750(9)$ \\
\hline $\mathrm{Fe}(1)-\mathrm{C}(12)$ & $1.877(11)$ & $1.891(6)$ & $1.894(8)$ \\
\hline $\mathrm{Fe}(2)-\mathrm{C}(12)$ & $1.961(11)$ & $1.965(6)$ & $1.944(8)$ \\
\hline $\mathrm{Fe}(1)-\mathrm{C}(13)$ & $1.944(10)$ & $1.959(5)$ & $1.955(7)$ \\
\hline $\mathrm{Fe}(2)-\mathrm{C}(13)$ & $2.051(10)$ & $2.032(5)$ & $2.035(7)$ \\
\hline $\mathrm{Fe}(2)-\mathrm{C}(14)$ & $2.044(10)$ & $2.034(5)$ & $2.080(7)$ \\
\hline $\mathrm{Fe}(2)-\mathrm{C}(15)$ & $1.868(12)$ & $1.841(5)$ & $1.839(7)$ \\
\hline $\mathrm{C}(11)-\mathrm{O}(11)$ & $1.144(11)$ & $1.134(8)$ & $1.150(9)$ \\
\hline $\mathrm{C}(12)-\mathrm{O}(12)$ & $1.195(10)$ & $1.164(7)$ & $1.181(9)$ \\
\hline $\mathrm{C}(13)-\mathrm{C}(14)$ & $1.447(12)$ & $1.428(8)$ & $1.39(1)$ \\
\hline $\mathrm{C}(14)-\mathrm{C}(15)$ & $1.454(13)$ & $1.433(7)$ & $1.43(1)$ \\
\hline $\mathrm{C}(13)-\mathrm{C}(25)$ & $1.511(12)$ & $1.509(7)$ & \\
\hline $\mathrm{C}(25)-\mathrm{O}(1)$ & $1.399(10)$ & $1.413(8)$ & \\
\hline$C(14)-S(1)$ & $1.795(10)$ & $1.800(5)$ & \\
\hline $\mathrm{C}(15)-\mathrm{N}(1)$ & $1.279(11)$ & $1.287(7)$ & $1.314(8)$ \\
\hline $\mathrm{N}(1)-\mathrm{C}(16)$ & $1.479(11)$ & $1.450(8)$ & $1.478(9)$ \\
\hline $\mathrm{N}(1)-\mathrm{C}(17)$ & $1.452(12)$ & $1.472(8)$ & $1.454(8)$ \\
\hline $\mathrm{C}(14)-\mathrm{C}(13)-\mathrm{Fe}(1)$ & $119.0(8)$ & $119.0(4)$ & $121.8(5)$ \\
\hline $\mathrm{C}(13)-\mathrm{C}(14)-\mathrm{C}(15)$ & $117.4(10)$ & $116.2(5)$ & $155.5(6)$ \\
\hline $\mathrm{N}(1)-\mathrm{C}(15)-\mathrm{C}(14)$ & $133.4(10)$ & $133.7(5)$ & $131.3(7)$ \\
\hline $\mathrm{O}(1)-\mathrm{C}(25)-\mathrm{C}(13)$ & $107.5(8)$ & $107.4(5)$ & \\
\hline Sum angles at N(1) & $359.3(16)$ & $359.9(9)$ & $360.0(9)$ \\
\hline
\end{tabular}


Table 2. Selected bond lengths $(\AA)$ and angles $\left(^{\circ}\right)$ for $\left[\mathrm{Fe}_{2}\left\{\mu-\mathrm{CN}(\mathrm{Me})\left(4-\mathrm{C}_{6} \mathrm{H}_{4} \mathrm{OMe}\right)\right\}(\mathrm{SPh})(\mu-\right.$ $\left.\mathrm{CO})(\mathrm{CO})(\mathrm{Cp})_{2}\right](3)$.

\begin{tabular}{|c|c|c|c|}
\hline $\mathrm{Fe}(1)-\mathrm{Fe}(2)$ & $2.5081(6)$ & $\mathrm{Fe}(2)-\mathrm{S}(1)$ & $2.3101(9)$ \\
\hline $\mathrm{Fe}(1)-\mathrm{C}(11)$ & $1.746(3)$ & $\mathrm{C}(11)-\mathrm{O}(11)$ & $1.148(4)$ \\
\hline $\mathrm{Fe}(1)-\mathrm{C}(12)$ & $1.969(3)$ & $\mathrm{C}(12)-\mathrm{O}(12)$ & $1.182(3)$ \\
\hline $\mathrm{Fe}(2)-\mathrm{C}(12)$ & $1.860(3)$ & $\mathrm{C}(13)-\mathrm{N}(1)$ & $1.303(3)$ \\
\hline $\mathrm{Fe}(1)-\mathrm{C}(13)$ & $1.897(3)$ & $\mathrm{Fe}(2)-\mathrm{C}(13)$ & $1.841(3)$ \\
\hline & & & $123.8(2)$ \\
\hline $\mathrm{Fe}(2)-\mathrm{C}(12)-\mathrm{Fe}(1)$ & $81.78(12)$ & $\mathrm{C}(13)-\mathrm{N}(1)-\mathrm{C}(15)$ & $122.4(3)$ \\
\hline $\mathrm{Fe}(2)-\mathrm{C}(13)-\mathrm{Fe}(1)$ & $84.28(12)$ & $\mathrm{C}(13)-\mathrm{N}(1)-\mathrm{C}(14)$ & $113.7(2)$ \\
\hline $\mathrm{C}(22)-\mathrm{S}(1)-\mathrm{Fe}(2)$ & $111.75(10)$ & $\mathrm{C}(15)-\mathrm{N}(1)-\mathrm{C}(14)$ & \\
\hline
\end{tabular}


Table 3

Crystal data and experimental details for $2 \mathrm{~d}\left[\mathrm{SO}_{3} \mathrm{CF}_{3}\right], \mathbf{2} \mathrm{e}\left[\mathrm{SO}_{3} \mathrm{CF}_{3}\right], \mathbf{3} \cdot \mathbf{0 . 5 E t _ { 2 }} \mathrm{O}$.

\begin{tabular}{|c|c|c|c|}
\hline Complex & $2 d$ & $2 e$ & $3 \cdot 0.5 \mathrm{Et}_{2} \mathrm{O}$ \\
\hline Formula & $\mathrm{C}_{32} \mathrm{H}_{30} \mathrm{~F}_{3} \mathrm{Fe}_{2} \mathrm{NO}_{6} \mathrm{~S}_{2}$ & $\mathrm{C}_{25} \mathrm{H}_{24} \mathrm{~F}_{3} \mathrm{Fe}_{2} \mathrm{NO}_{6} \mathrm{~S}_{2}$ & $\mathrm{C}_{29} \mathrm{H}_{30} \mathrm{Fe}_{2} \mathrm{NO}_{3.5} \mathrm{~S}$ \\
\hline$F_{\mathrm{W}}$ & 757.39 & 667.27 & 592.30 \\
\hline$T, K$ & 293(2) & 293(2) & $296(2)$ \\
\hline$\lambda, \AA$ & 0.71073 & 0.71073 & 0.71073 \\
\hline Crystal system & Triclinic & Monoclinic & Monoclinic \\
\hline Space group & $P \overline{1}$ & $P 2_{1} / c$ & $C 2 / c$ \\
\hline$a, \AA$ & $11.233(5)$ & $10.302(2)$ & $22.2055(14)$ \\
\hline$b, \AA$ & $11.463(5)$ & $23.461(5)$ & $14.0250(9)$ \\
\hline$c, \AA$ & $13.083(6)$ & $11.478(2)$ & $17.4654(11)$ \\
\hline$\alpha$, & $94.747(5)$ & 90 & 90 \\
\hline$\beta,^{\circ}$ & $98.265(6)$ & $100.65(3)$ & $94.6860(10)$ \\
\hline$\gamma{ }^{\circ}$ & $98.950(5)$ & 90 & 90 \\
\hline Cell volume, $\AA^{3}$ & 1637.3(12) & $2726.3(10)$ & $5421.1(6)$ \\
\hline$Z$ & 2 & 4 & 8 \\
\hline$D_{\mathrm{c}}, \mathrm{g} \mathrm{cm}^{-3}$ & 1.536 & 1.626 & 1.451 \\
\hline$\mu, \mathrm{mm}^{-1}$ & 1.075 & 1.279 & 1.180 \\
\hline $\mathrm{F}(000)$ & 776 & 1360 & 2456 \\
\hline Crystal size, mm & $0.18 \times 0.16 \times 0.11$ & $0.22 \times 0.15 \times 0.11$ & $0.22 \times 0.16 \times 0.12$ \\
\hline$\theta$ limits, ${ }^{\circ}$ & $1.58-23.00$ & $1.74-25.55$ & $1.72-27.00$ \\
\hline Reflections collected & 8764 & 25188 & 27894 \\
\hline Independent reflections & $4506\left[R_{\text {int }}=0.1602\right]$ & $\begin{array}{c}5102\left[R_{\text {int }}=\right. \\
0.0729]\end{array}$ & $\begin{array}{c}5895\left[R_{\text {int }}=\right. \\
0.0454]\end{array}$ \\
\hline Data/restraints/parameters & $4506 / 163$ / 421 & $5102 / 130 / 353$ & $5895 / 7 / 7813$ \\
\hline Goodness on fit on $\mathrm{F}^{2}$ & 0.811 & 1.063 & 1.013 \\
\hline $\mathrm{R}_{1}[I>2 \sigma(I))$ & 0.0577 & 0.0647 & 0.0391 \\
\hline$w \mathrm{R}_{2}$ (all data) & 0.1237 & 0.1906 & 0.1158 \\
\hline $\begin{array}{c}\text { Largest diff. peak and hole, } \\
\text { e. } \AA^{-3}\end{array}$ & $0.322 /-0.353$ & $0.877 /-0.869$ & $0.416 /-0.277$ \\
\hline
\end{tabular}




\title{
Graphical abstract
}

\section{SPh functionalized bridging-vinyliminium diiron complexes}

\author{
Luigi Busetto ${ }^{\text {a }}$, Fabio Marchetti ${ }^{\mathrm{b}}$, Rita Mazzoni ${ }^{\mathrm{a}}$, Mauro Salmi ${ }^{\mathrm{a}}$, \\ Stefano Zacchini ${ }^{\text {a }}$, Valerio Zanotti ${ }^{\mathrm{a} *}$. \\ ${ }^{a}$ Dipartimento di Chimica Fisica e Inorganica, Università di Bologna, Viale Risorgimento 4, \\ I-40136 Bologna, Italy \\ ${ }^{b}$ Dipartimento di Chimica e Chimica Industriale, Università di Pisa, Via \\ Risorgimento 35, I-56126 Pisa, Italy.
}

$\mathrm{SPh}$ functionalized bridging-vinyliminium complexes $\mathbf{2}$ are conveniently obtained by reaction of the corresponding vinyliminium precursors $\mathbf{1}$ upon treatment with phenyldisulphides in the presence of $\mathrm{NaH}$.
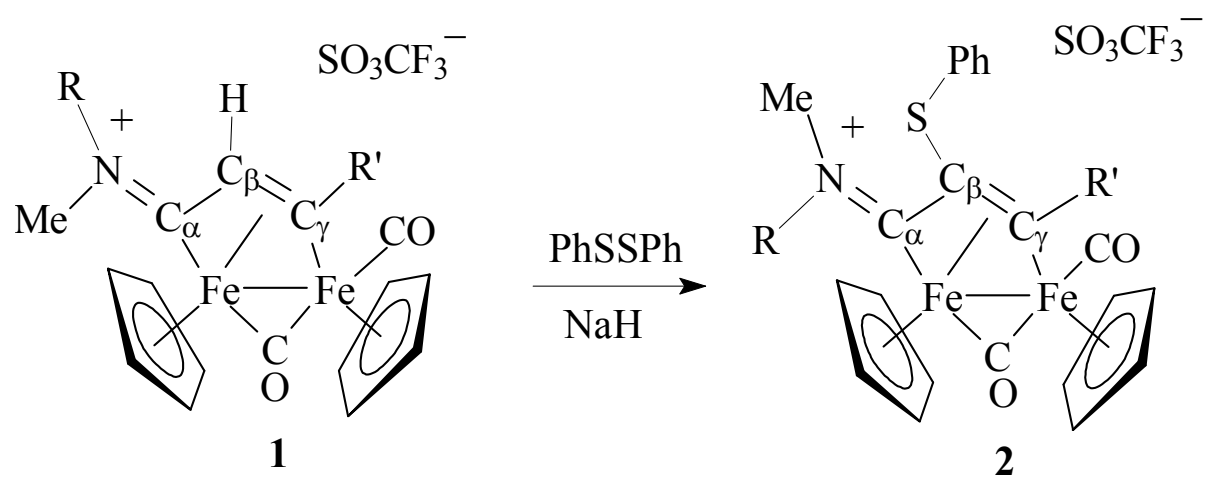